\title{
The provision, employment and educational attainment of technically skilled workers across industrialised countries
}

Citation for published version (APA):

Cörvers, F., de Grip, A., \& van Loo, J. B. (1997). The provision, employment and educational attainment of technically skilled workers across industrialised countries. Researchcentrum voor Onderwijs en Arbeidsmarkt, Faculteit der Economische Wetenschappen. ROA Reports No. 5E https://doi.org/10.26481/umarep.199705E

Document status and date:

Published: 01/01/1997

DOI:

10.26481/umarep.199705E

Document Version:

Publisher's PDF, also known as Version of record

Please check the document version of this publication:

- A submitted manuscript is the version of the article upon submission and before peer-review. There can be important differences between the submitted version and the official published version of record.

People interested in the research are advised to contact the author for the final version of the publication, or visit the DOI to the publisher's website.

- The final author version and the galley proof are versions of the publication after peer review.

- The final published version features the final layout of the paper including the volume, issue and page numbers.

Link to publication

\footnotetext{
General rights rights.

- You may freely distribute the URL identifying the publication in the public portal. please follow below link for the End User Agreement:

www.umlib.nl/taverne-license

Take down policy

If you believe that this document breaches copyright please contact us at:

repository@maastrichtuniversity.nl

providing details and we will investigate your claim.
}

Copyright and moral rights for the publications made accessible in the public portal are retained by the authors and/or other copyright owners and it is a condition of accessing publications that users recognise and abide by the legal requirements associated with these

- Users may download and print one copy of any publication from the public portal for the purpose of private study or research.

- You may not further distribute the material or use it for any profit-making activity or commercial gain

If the publication is distributed under the terms of Article 25fa of the Dutch Copyright Act, indicated by the "Taverne" license above, 


\section{The Provision, Employment and Educational Attainment of Technically Skilled Workers across Industrialised Countries}

ROA-R-1997/5E

Frank Cörvers
Andries de Grip
Jasper van Loo

Research Centre for Education and the Labour Market

Faculty of Economics and Business Administration Maastricht University

Maastricht, June 1997 
ISBN 90-5321-209-4 SEC97.014/FC 


\section{Contents}

Page

Acknowledgements

Résumé

1 Introduction 1

2 Comparative country analysis 5

2.1 Introduction 5

2.2 Provision of technically skilled workers (educational background) 5

2.3 Employment shares of technical workers (occupational background) 8

2.4 Educational attainment of technical workers (occupational 12 background)

$\begin{array}{ll}2.5 \text { Summary } & 17\end{array}$

3 Comparative sector analysis between countries $\quad 19$

$\begin{array}{ll}3.1 \text { Introduction } & 19\end{array}$

3.2 Employment shares of technical workers by economic sector $\quad 19$ (occupational background)

3.3 Educational attainment of technical workers by economic sector 26 (occupational background)

$\begin{array}{ll}3.4 \text { Summary } & 30\end{array}$

4 Conclusions and summary 33

4.1 General conclusions $\quad 33$

4.2 Summary of data analysis $\quad 34$

$\begin{array}{ll}\text { References } & 37\end{array}$

Appendix A Definitions of technical fields of study according to ISCED 39

Appendix B Definitions of technical occupations $\quad 41$

Appendix C Definitions of economic activities $\quad 43$

Appendix D Contact persons $\quad 45$ 


\section{Acknowledgements}

We would like to thank Edmée Tuyl of the Ministry of Economic Affairs for her useful comments on earlier versions of the report. The following persons we acknowledge for their assistance in collecting and processing the data: Astrid Matheeuwsen, Rob Wilson, John Cuthbert, Jayne Middlemas, Civ Cromtton, Kaj Olesen, Metter Bier Paulsen, Hans Dietrich, Fritz Spahni, Dominik Ullmann, Jaap van Dam, Paula Knepper, Rosalind Bruno, Paul Ghijsen, Hiroshi Nishizawa, Hiroyuki Tomizawa, Albert Tuynman, Didier Lesnicki and Nick Jagger. 


\section{Résumé}

Both adequate employment of technical workers and an adequate skill level of these workers constitute the basis for continuous technological development and economic growth. However, due to the relatively small industrial sector and the relatively large services sector, the Netherlands is expected to have a proportionally small provision and employment share of technically skilled workers relative to other industrialised countries.

This report focuses on four questions:

1. Is the expectation justified that both the provision and the employment of technically skilled workers in the Netherlands are low relative to other industrialised countries? This was the main question of the report. The available data indeed confirm the low provision of technically (highly)-skilled workers as well as the low employment share of technical workers in the Netherlands relative to other industrialised countries. The Netherlands has, after the United States, the smallest share of students enrolled in the various technical fields of study in higher education (18\%). In addition, the Netherlands has the lowest employment share of technical workers $(21 \%)$ of all countries selected.

2. Is the assumption justified that the employment share of technical workers in the services sector is low relative to the industrial sector?

The available data indeed reveal that in all countries the services sectors have smaller employment shares of technical workers than the industrial sectors. This finding justifies the assumption on which the expectation mentioned in the first question is based.

3. How large are the employment shares of technical workers at sector level across countries?

This question was asked to exclude the impact of the sectoral distribution on the share of technical workers. It can be concluded that the relatively low share of technical workers is not merely related to the sector structure of employment. In many economic sectors of the Netherlands, the employment shares of technical workers are below average. The employment share of technical workers in the manufacturing sector of the Netherlands is, after Switzerland, the smallest (50\%) of all countries selected.

From the above three findings, the important conclusion can be drawn that the relatively small employment share of the Netherlands at the country level is the result of both the services-oriented sector structure of the economy and the relatively small employment shares of technical workers in many economic sectors, including manufacturing. 
4. What is the level of education of technically skilled workers in the Netherlands relative to other industrialised countries?

It was found that the employment share of intermediate-skilled workers in technical occupations in the Netherlands is the largest $(68 \%)$ relative to the other industrialised countries. It was shown that the ablest share of the population (i.e. the sum of the intermediate and the highly-skilled) in the Netherlands is overrepresented in the most productive occupations, including the technical occupations. The fact that workers with the highest ability level in the Netherlands are relatively often employed in technical occupations is favourable for economic growth. However, in some technical occupations in the Netherlands, the skill level index measured by the average number of years of education is low relative to other industrialised countries.

An important point of interest is whether the relatively low provision of technically (highly)-skilled workers in the Netherlands is determined by the economic structure of the Netherlands or the relatively low provision of technically skilled workers is a major disadvantage for firms that need these workers (e.g. firms in the industrial sector) to start or expand their business in the Netherlands. The Netherlands is known for its relatively large services sector, which partly explains the small employment share of technical workers at the national level. However, this cannot explain the small employment share of technical workers in the manufacturing sector of the Netherlands. If the demand for technical workers by the manufacturing sectors is assumed to be similar across industrialised countries then the relatively low employment share of technical workers in the Netherlands is probably to a large extent due to the relatively low supply of technically educated workers on the Dutch labour market. 
$\ldots \ldots$ 


\section{Introduction}

Introducing new technologies and products to achieve higher economic growth requires an educated labour force (Soete and Verspagen, 1993, Hoevenberg and De Grip, 1994). In particular an adequate provision and employment level of technically skilled workers may be regarded as a prerequisite for technological developments (see e.g. Van Duyn, 1992), since these workers are the first and most directly involved in the diffusion of new technologies and research and development on process and product innovations. The relevance of technically skilled workers for economic growth was illustrated by Murphy et al. (1991). They present a model that shows the importance for economic growth of allocating the ablest workers to the most productive jobs, which include the technical occupations such as those in engineering. The ability of workers in technical occupations is here indicated by the educational attainment of workers in technical occupations. We can see that the provision, the employment and the educational attainment of technically skilled workers can be an important policy instrument for the Dutch government to stimulate economic growth. Monitoring the labour market with regard to the demand and supply of technically skilled workers may be very useful, since in particular a shortfall of technically skilled workers may endanger economic growth in the long run. ${ }^{1}$

The fact that the Netherlands has a relatively small industrial sector and a relatively large services sector ${ }^{2}$ raises the expectation that both the provision and the employment share of technically skilled workers in the Netherlands are proportionally small relative to other industrialised countries. This expectation is based on two different explanations: a supply-side and a demand-side argument. On the one hand, the supply of skills affects the sectoral production structure of countries (e.g. Cörvers and Reininga, 1996; Cörvers and De Grip, 1997). For example, if students in the Netherlands choose technical studies less often than their colleagues in other countries, then the relatively low supply of technically skilled workers in the Netherlands could lead to an upward pressure on the wage level of these workers. This, in turn, may lead to less technically oriented production activities and a small industrial sector relative to other countries. On the other hand the sectoral structure of the economy determines the demand for skills (e.g. Cörvers, 1997). If the demand for technical skills in the

1. Information on the labour market developments of all occupations and all types of education, including the technical occupations and the technical types of education, for the Netherlands can be found in the report The Labour Market by Education and Occupation to 2000 by the Research Centre for Education and the Labour Market (1995).

2. The employment share of the industrial sector in the total economy of the Netherlands is $23 \%$, whereas the employment share of the services sector in the total economy of the Netherlands is $73 \%$ (1994 figures). All countries of the sample in this report (see below) have larger employment shares for the industrial sector and smaller employment shares for the services sector, except for the United States. The employment share of the industrial sector in the United States is comparable to the share in the Netherlands (OECD, 1996; Den Broeder, 1996). 
Netherlands is relatively low due to the relatively large services sector, then the relatively low demand of technically skilled workers puts a downward pressure on the wage level of these workers. As a result, relatively few students are willing to learn technical skills. However, before distinguishing the supply-side and demand-side arguments, it is necessary to have information on the provision and employment of technically skilled workers. We will return to the supply-side and demand-side arguments in the concluding chapter.

The report focuses on four questions:

1. Is the expectation justified that both the provision and the employment of technically skilled workers in the Netherlands are low relative to other industrialised countries? The the sectoral distribution of the Netherlands shows a relatively large services sector, which was the immediate cause for formulating this expectation.

2. Is the assumption justified that the employment share of technically skilled workers in the services sector is low relative to the industrial sector? The expectation mentioned in the first question is based on the assumption that the employment share of technically skilled workers in the services sector is low relative to the industrial sector, which requires the investigation of this assumption.

3. How large are the employment shares of technically skilled workers at sector level across countries? This question was asked to exclude the impact of the sectoral distribution on the share of technical workers.

4. What is the level of education of technically skilled workers in the Netherlands relative to other industrialised countries? As stated before, an adequate level of education of technically skilled workers may be very important for economic growth.

In the remainder of this introduction three points of interest are discussed with regard to the provision, employment and educational attainment of technically skilled workers. Firstly, a uniform definition of technically skilled workers is required to investigate the provision of these workers by the different national educational systems. For the Netherlands, the technically skilled workers can be defined relatively easily by their educational background at all levels of education. Students in the Netherlands may take a technical education at a technical school. However, students in most other countries take a general or vocational education, and take classes in technical subjects, among other subjects, during their vocational education. In these countries students' choices of technical subjects at the secondary level of education are unknown to the national bureaus of statistics. Moreover, the diplomas with regard to the technical subjects are often not internationally comparable between countries. However, at the tertiary level the choices of students are known in most countries, as is the number of graduates in the fields of study. Therefore this report only investigates the provision of third-level students and graduates across countries. For the purpose of this report the technical fields of study at the tertiary level only include the natural and technical sciences (CBS, 1996). The field of studies belonging to these sciences have been selected from the definitions according to the International Standard Classification of Education (ISCED; 
see CBS, 1996, and appendix A for the tertiary technical fields of study). The report uses the term technically skilled workers to refer to workers with an educational background in one of the technical fields of study. ${ }^{3}$

Secondly, the employment of technically skilled workers in the Netherlands relative to other industrialised countries is investigated by distinguishing technical occupations (at all occupational levels) that are related to the technical fields of study in appendix $A$. The technical occupations have been selected from the International Standard Classification of Occupations (ISCO 88; see appendix B). Workers employed in technical occupations are called technical workers throughout the report. These workers are supposed to have a technically skilled background. The occupational data have the advantage of being widely available and internationally comparable at all levels of education. However, it should be noted that technically skilled workers could also be employed in non-technical jobs, whereas in particular in some lower skilled technical occupations part of the workers may not have a technical educational background (Borghans et al., 1995).

Thirdly, to indicate the level of educational attainment of technical workers, a distinction is made between low, intermediate and highly-skilled (technical) workers. The definition of these levels of education is according to the ISCED, which is used by both the UNESCO and the OECD. Low-skilled workers have only enjoyed pre-primary, primary or lower secondary education (ISCED levels 0,1 and 2, respectively), whereas intermediate-skilled workers have completed upper secondary education (ISCED level 3). Highly-skilled workers have completed third level education at a non-academic level, an academic level or a post-academic level (ISCED levels 5, 6 and 7, respectively). ${ }^{4}$

The analysis focuses on the position of the Netherlands relative to Denmark, Germany, Japan, Switzerland, the United Kingdom and the United States, which are called the 'key countries' in this report. These countries are either the major countries in the world economy or relatively small European countries like the Netherlands. Furthermore, the Member States of the European Union (EU) are also included in the comparative country analysis, since these countries are expected to become economically and politically more integrated with the Netherlands in the near future. The further integration of the Member States in the EU may imply that it becomes increasingly important for the

3. This selection of technical fields of study differs from the selection of fields of study that is used by Statistics Netherlands (CBS, 1996) to indicate the human resources in science and technology. The definition of human resources in science and technology of Statistics Netherlands refers to all workers with a tertiary level of education or with an occupation at a higher level, i.e. all legislators, senior officials, managers, professionals and technicians. The definition in this report does not explicitly refer to science and technology workers.

4. See OECD $(1995,1996 a)$ and Eurostat (1992) for a comprehensive list of the types of education, the attainment levels and the charts of education systems. 
Netherlands to use the remaining opportunities of 'policy competitiveness' between the Member States, for example with regard to labour market policies (Geelhoed, 1997).

The report is structured as follows. Chapter 2 deals with the provision of technically skilled workers at the tertiary level of education by the countries' national education systems, the employment shares of technical workers and the educational attainment of technical workers in the countries of the sample. Furthermore, reference is made to the employment and educational attainment of technical workers engaged in research and development activities. Chapter 3 presents a sector analysis with respect to the employment shares of technical workers and the educational attainment of these workers in the above-mentioned countries. Both chapters 2 and 3 end with a summary. Chapter 4 concludes and summarizes. 


\section{Comparative country analysis}

\subsection{Introduction}

In this chapter a comparative country analysis will be given with respect to the employment and the skills of the work force. First, section 2.2 considers the provision of technically skilled workers at the tertiary level of education in the various countries of the sample. ${ }^{5}$ The provision of technically educated workers is indicated by the shares of students, graduates and workers with a technical educational background. Moreover, the availability of technically skilled workers in research and development activities is shown. Section 2.3 compares both the level and the increase of the employment shares of technical workers (defined by occupational background, see chapter 1) in the countries selected, including the employment shares of technical workers at three levels of education. Section 2.4 indicates the skill level of technical workers across countries and compares it with the level of educational attainment of the whole population in the various countries. Finally, section 2.5 summarizes.

\subsection{Provision of technically skilled workers (educational background)}

Table 2.1 presents the percentage of students enrolled in a technical field of study at the tertiary level of education. ${ }^{6}$ The table shows that the Netherlands, relative to most other countries, has a relatively small share of students in most technical fields of study at the tertiary level. An exception is the percentage of students in the Netherlands that is enrolled in trade, craft and industrial programs. The total share of students enrolled in a technical field of study is less than $20 \%$ only in the Netherlands, the United States and Japan. Whereas this share is remarkably low in Japan, the low shares of students enrolled in a technical field of study in the Netherlands and the United States are consistent with the relatively low employment shares of the industrial sector in these countries.

Furthermore, Germany has a very large share of students in both natural science and engineering. France and Ireland also have large shares of students in natural science, whereas Finland has a large share of students in engineering. The shares of students in engineering is relatively small in the United States and France. Moreover, in particular Italy and to a lesser extent Austria, Switzerland and Spain have large shares of students

5. As mentioned in chapter 1 , there are no internationally comparable data with regard to the provision of technically skilled workers at the primary and secondary level of education.

6. It should be noted that the OECD and the UNESCO include various technical courses of different educational systems of countries in the technical fields of study presented in tables 2.1, 2.2 and 2.3. The harmonisation of the data by the OECD and UNESCO may be difficult and arbitrary to some extent. 


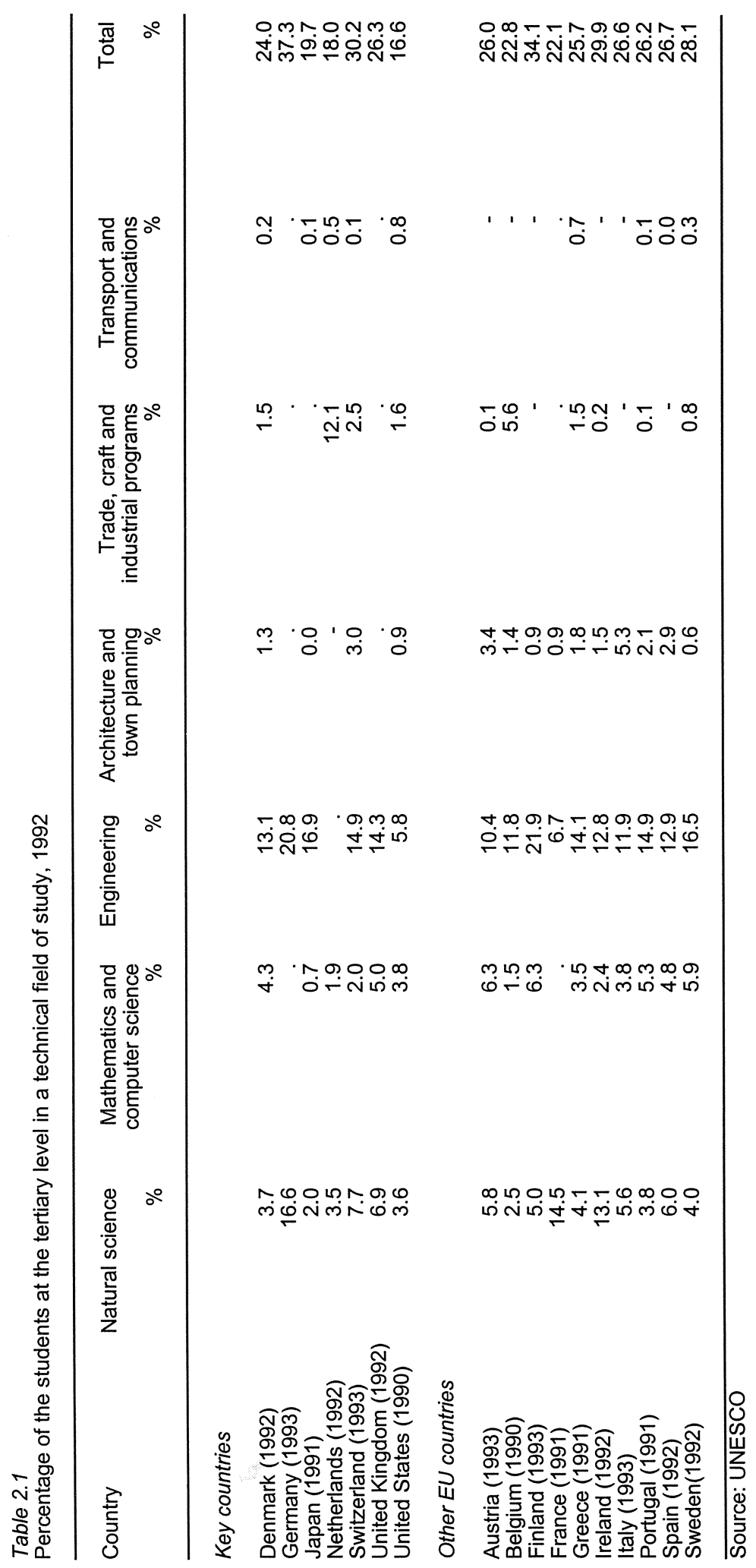


in architecture and town planning. The total share of students is larger than $30 \%$ only in Germany, Switzerland and Finland.

Table 2.2 shows the shares of non-university and university graduates in only three technical fields of study, i.e. natural science, mathematics and computer science, and engineering and architecture. Relative to other countries, the Netherlands has small shares of graduates in these technical fields of study, which confirms the general picture from table 2.1 for the Netherlands. The share of graduates in natural science is remarkably large in Ireland, whereas the share of graduates in mathematics and computer science is remarkably large in France and the share of graduates in engineering and architecture is large in Germany, Japan, Finland, Greece and Ireland.

Table 2.2

Percentage of graduates at the tertiary level that has a degree in a technical field of study, 1994

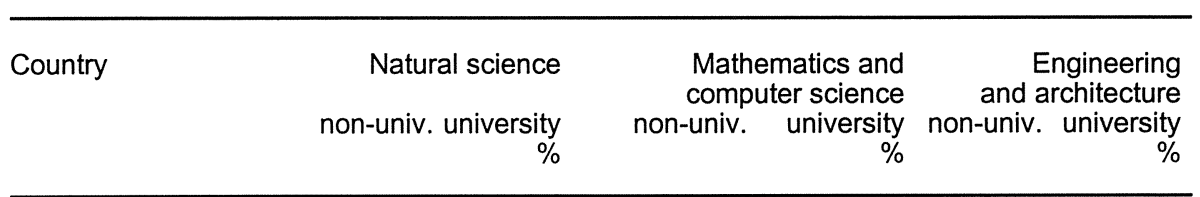

Key countries

\begin{tabular}{|c|c|c|c|c|c|c|}
\hline Denmark* & 3.2 & 6.6 & - & 1.3 & - & 15.5 \\
\hline Germany* & 6.4 & 12.6 & 0.7 & 5.5 & 24.7 & 23.2 \\
\hline Japan & 14.0 & 9.6 & . & & 18.6 & 21.5 \\
\hline Netherlands* & & 6.6 & . & 2.5 & . & 13.4 \\
\hline Switzerland & & 16.3 & & 3.4 & & 11.6 \\
\hline United Kingdom & 7.8 & 11.6 & 1.3 & 5.8 & 16.3 & 14.3 \\
\hline United States & 4.3 & 7.3 & 2.1 & 3.3 & 6.8 & 7.6 \\
\hline \multicolumn{7}{|c|}{ Other EU countries } \\
\hline Austria & 1.8 & 11.5 & 0.8 & 5.4 & 14.2 & 13.3 \\
\hline Belgium* & 2.0 & 9.3 & 4.3 & 2.1 & 1.1 & 20.6 \\
\hline Finland & 8.7 & 8.8 & 5.3 & 7.1 & 16.6 & 24.3 \\
\hline France* $^{*}$ & & & 15.1 & 20.9 & 15.6 & 11.7 \\
\hline Greece* & 8.5 & 10.7 & 0.8 & 3.7 & 21.5 & 10.7 \\
\hline Ireland* & 16.0 & 13.5 & 7.7 & 5.0 & 27.6 & 11.5 \\
\hline Italy & & 8.8 & & 2.9 & & 11.9 \\
\hline Portugal & 4.3 & 5.9 & 2.5 & 2.5 & 13.2 & 13.3 \\
\hline Spain* & 0.9 & 6.8 & & 3.7 & & 9.5 \\
\hline Sweden & 2.0 & 6.8 & 2.1 & 5.2 & 10.3 & 15.9 \\
\hline
\end{tabular}

* Data refer to 1993

Source: OECD

Table 2.3 presents the shares of the labour force in the 25-34 age group with a tertiary science degree. We can see that the share of the labour force in the 25-34 age group with a university science degree for the Netherlands is small, if the share of the labour force in the 25-34 age group with a non-university tertiary science degree of the other countries is also included in the analysis. In particular Ireland and Japan, and to a lesser extent the United Kingdom, France, the United States and Germany reveal large shares of technically educated workers. 
Table 2.3

Percentage of the labour force with a tertiary science degree* ${ }^{*}$ 25-34 age group, 1994

\begin{tabular}{rrr}
\hline Country & High (total) & University \\
$\%$ & $\%$ \\
\hline
\end{tabular}

Key countries

\begin{tabular}{|c|c|c|}
\hline & & \\
\hline Denmark ** & 0.81 & 0.78 \\
\hline Germany ** & 1.06 & 0.74 \\
\hline Japan & 2.68 & 1.22 \\
\hline Netherlands ** & & 0.78 \\
\hline Switzerland & & 0.42 \\
\hline United Kingdom & 1.80 & 1.19 \\
\hline United States & 1.18 & 0.89 \\
\hline Other EU countri & & \\
\hline Austria & 0.41 & 0.34 \\
\hline Belgium ** & 0.81 & 0.63 \\
\hline France ** & 1.67 & 0.74 \\
\hline Greece ** & 0.67 & 0.46 \\
\hline Ireland ** & 2.75 & 1.31 \\
\hline Portugal & 0.67 & 0.48 \\
\hline Spain ** & 0.66 & 0.66 \\
\hline Sweden & 0.75 & 0.56 \\
\hline
\end{tabular}

* The data contain graduates in the following fields of study: natural science, mathematics and computer science, engineering, architecture and town planning, agriculture, forestry and fishery, and home economics (domestic science). The last two fields of study, home economics (domestic science) and agriculture, forestry and fishery, are not incorporated in the definition of technically skilled workers in this report.

** Data refer to 1993

Source: OECD

Table 2.4 shows the number of scientists and engineers and technicians in research development activities per thousand population in the countries selected. The table shows that the Netherlands has the fifth largest number of scientists and technicians after Japan, the United States, Sweden and West-Germany. Furthermore, the number of scientists and engineers is low in Greece, Portugal and Spain.

With regard to the number of technicians, the Netherlands takes an intermediate position. Relative to the other key countries, the number of technicians is remarkably small in Japan. The number of technicians is small in Greece, Ireland, Italy, Portugal and Spain, whereas it is large in Denmark, France and Sweden.

\subsection{Employment shares of technical workers (occupational background)}

Table 2.5 presents the shares of technical workers in the work force of the countries selected. The table shows that the Netherlands has the smallest share of technical workers relative to all other countries: $21.0 \%$. As stated in the introduction of the report, the small industrial sector of the Netherlands may be an explanation of the small share of technical workers in the Netherlands. The United States, Ireland and Greece have slightly larger shares of technical workers than the Netherlands. However, in particular 
in Germany, Japan and Italy the shares of technical workers are much greater, even exceeding $30 \%$.

Table 2.4

Scientists, engineers and technicians engaged in research and development, per thousand population, 1991

\begin{tabular}{lcr}
\hline Country & Scientists and engineers & $\begin{array}{r}\text { Technicians } \\
\% \\
\%\end{array}$ \\
\hline
\end{tabular}

Key countries

$\begin{array}{lrr}\text { Denmark } & 2.3 & 2.7 \\ \text { West-Germany (1989) } & 2.9 & 2.0 \\ \text { Japan (1992) } & 5.7 & 0.9 \\ \text { Netherlands } & 2.7 & 1.8 \\ \text { Switzerland (1989) } & 2.4 & 1.4 \\ \text { United Kingdom } & 3.9 & . \\ \text { United States (1988) } & & \\ \text { Other EU countries } & & 1.1 \\ \text { Austria (1989) } & & 2.0 \\ \text { Belgium (1990) } & 1.2 & 2.1 \\ \text { Finland } & 1.9 & 3.0 \\ \text { France } & 2.3 & 0.0 \\ \text { Greece (1986) } & 2.3 & 0.4 \\ \text { Ireland (1988) } & 0.1 & 0.7 \\ \text { Italy (1990) } & 1.8 & 0.4 \\ \text { Portugal (1990) } & 1.4 & 0.3 \\ \text { Spain (1990) } & 0.6 & 3.1 \\ \text { Sweden } & 1.0 & 3.1 \\ \end{array}$

Source: UNESCO

Table 2.6 presents the shares of technical workers of the 26-35 and 55-65 age groups for the countries selected. The absolute technical skill trend shows the difference in the shares of technical workers between these two age groups, whereas the relative technical skill trend shows the share of technical workers of the 26-35 age group divided by the share of technical workers of the 55-65 age group. The (absolute or relative) technical skill trend of the share of technical workers may be based on two different developments. Firstly, it may indicate the change in the share of technical workers over a period of 30 years. Secondly, it may indicate the shift in the position of the workers during their working career from technical to non-technical (e.g. management) jobs. In most countries the share of technical workers is larger in the 26-35 age group than in the 55-65 age group, except in Japan. In particular in Portugal, Ireland and Greece the increase of the share of technical workers is relatively large. The negative absolute technical skill trend in Japan may indicate a smaller supply of technically educated 
school-leavers ${ }^{7}$ and graduates on the Japanese labour market and/or growing employment in non-technical jobs for youngsters in this country.

Table 2.5

Percentage of technical workers in the working population of 15 years of age and older, 1994

Country

Technical workers

Key countries

Denmark

Germany

Japan

Netherlands

21.0

Switzerland ${ }^{*}$

United Kingdom

United States ${ }^{\star \star}$

Other EU countries

Belgium

France

Ireland

22.0

Italy

30.4

Portugal

28.3

Spain

26.4

* data refer to 1990 and are based on educational background instead of occupational background

** data refer to 1995

Source: Eurostat, Bundesamt für Statistik Switzerland, Statistics Bureau Japan, U.S. Census Bureau

Next, table 2.7 shows the shares of technical workers at three levels of educational attainment: low, intermediate and highly-skilled. We can see that the Netherlands has, relative to the other key countries, the smallest share of technical workers at all levels of education. Among these key countries, Japan and the United States have large shares of technical workers at the low-skill level, whereas Germany has by far the largest share of technical workers at the high-skill level. The other EU countries, in particular Italy and Portugal have small shares of technical workers at the high-skill level. In general, the differences in shares of technical workers between the Netherlands and the other countries are much smaller at the high-skill level than at the low-skill and intermediate-skill levels.

7. This may be in line with the result for Japan in table 2.1 , which reveals a remarkably low share of students in technical fields of study. 
Table 2.6

Percentage of technical workers in the working population, 26-35 and 55-65 age groups, 1994

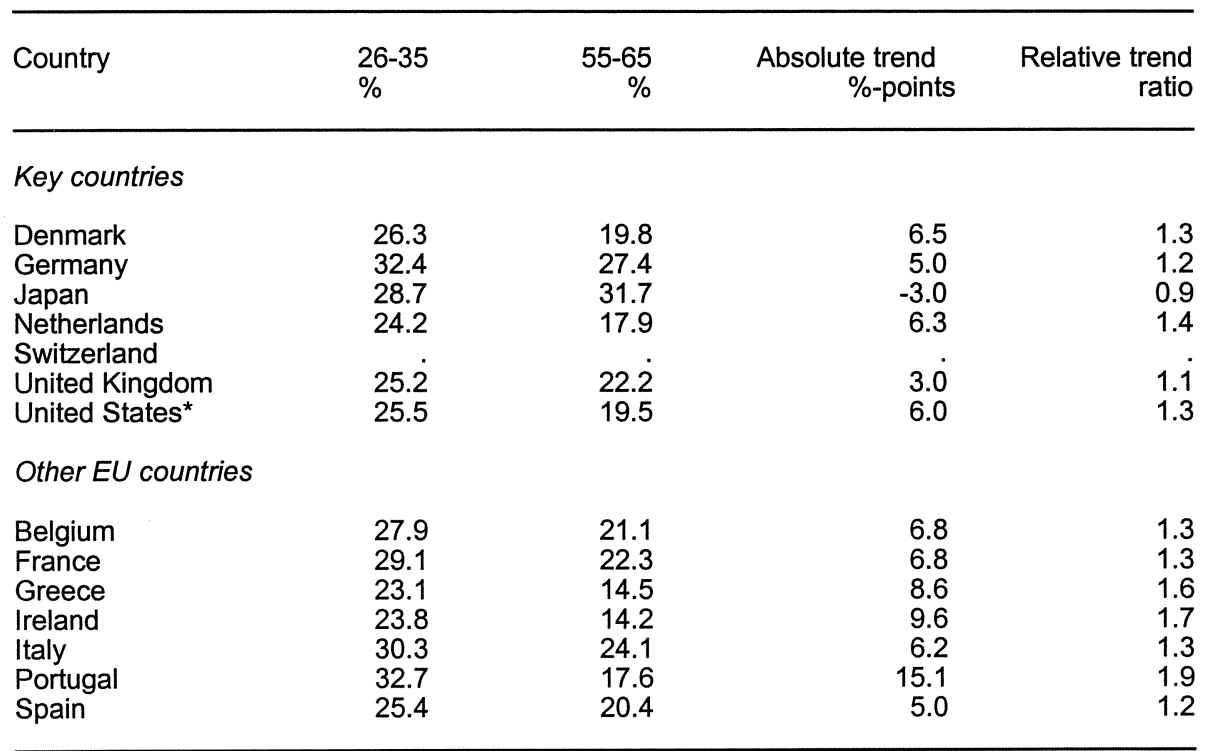

* data refer to 1995

Source: Eurostat, Statistics Bureau Japan, U.S. Census Bureau

Table 2.7

Percentage of technical workers in the working population at three levels of education, 1994

\begin{tabular}{lrrr}
\hline Country & Low & Intermediate & High \\
$\%$ & & $\%$
\end{tabular}

Key countries

\begin{tabular}{lccr} 
Denmark & 21.7 & 27.7 & 17.9 \\
Germany & 29.8 & 31.0 & 30.6 \\
Japan & 43.0 & 31.5 & 18.5 \\
Netherlands & 18.8 & 23.8 & 15.4 \\
Switzerland & 19.1 & 31.4 & 19.7 \\
United Kingdom & 31.5 & 24.4 & 16.4 \\
United States* & & & \\
Other EU countries & & & \\
& & 28.4 & 15.6 \\
Belgium & 35.3 & 31.1 & 18.1 \\
France & 30.0 & 20.2 & 16.1 \\
Greece & 25.6 & 18.9 & 18.2 \\
Ireland & 26.9 & 23.6 & 10.7 \\
Italy & 38.4 & 18.0 & 11.2 \\
Portugal & 32.8 & 19.7 & 20.2 \\
Spain & 30.0 & & \\
\hline
\end{tabular}

* data refer to 1995

Source: Eurostat, Statistics Bureau Japan, U.S. Census Bureau 


\subsection{Educational attainment of technical workers (occupational background)}

Table 2.8 focuses on the skill level of technical workers. The table distinguishes three skill groups of technical workers for the countries selected. The table shows that the Netherlands has, relative to the other key countries, the smallest share of highly-skilled workers in the total number of technical workers. Relative to all countries selected the Netherlands takes an intermediate position, whereas Germany and the United States have the largest shares of highly-skilled workers in the total number of technical workers, followed by Ireland, Denmark and the United Kingdom. The share of highlyskilled workers is by far the smallest in Italy and Portugal.

Table 2.8

Educational attainment level of technical workers in the working population by the highest completed level of education, in percentages, 1994

\begin{tabular}{lrrr}
\hline Country & $\begin{array}{r}\text { Low } \\
\%\end{array}$ & $\begin{array}{r}\text { Intermediate } \\
\%\end{array}$ & $\begin{array}{r}\text { High } \\
\%\end{array}$ \\
\hline Key countries & & & \\
Denmark & & & \\
Germany & 20.2 & 60.6 & 19.2 \\
Japan & 14.4 & 62.3 & 17.3 \\
Netherlands & 31.3 & 50.6 & 17.3 \\
Switzerland & 14.7 & 68.0 & 19.2 \\
United Kingdom & 35.4 & 45.4 & 24.0 \\
United States* & 8.8 & 67.2 & \\
& & & 17.2 \\
Other EU countries & & & 13.3 \\
& & 38.0 & 20.6 \\
Belgium & 44.8 & 50.7 & 3.4 \\
France & 36.0 & 27.3 & 15.8 \\
Greece & 60.5 & 28.8 & \\
Ireland & 50.6 & 7.7 & \\
Italy & 68.6 & 11.6 & \\
Portugal & 87.5 & & \\
Spain & 73.0 & & \\
& & & \\
\hline
\end{tabular}

* data refer to 1995

Source: Eurostat, Statistics Bureau Japan, U.S. Census Bureau

The table also shows that the Netherlands has the largest share of intermediate-skilled workers in the total number of technical workers: $68 \%$. Denmark, Germany and the United States also have large shares of intermediate-skilled workers in the total number of technical workers. On the other hand, Portugal and Spain have the smallest shares of intermediate-skilled workers in the total number of technical workers. In both countries the greater part of the technical workers is low-skilled. This also holds to a lesser degree for Italy and Greece.

As argued in chapter 1 , the level of educational attainment of technical workers relative to the level of educational attainment of the labour force is important for economic growth perspectives. Therefore the level of educational attainment of the total 
population (25-64 years old) is presented and discussed first ${ }^{8}$. Table 2.9 shows that both in the Netherlands and in Denmark, relative to the other key countries, a large proportion of the population is only low-skilled, whereas a relatively small proportion of the population is intermediate-skilled. Similarly, Den Broeder (1996) found that relative to the four countries of reference in her study (Germany, the United Kingdom, the United States and Sweden) the Dutch educational attainment level with regard to intermediate skills lags behind. However, most other Member States of the European Union show even larger proportions of low-skilled and smaller proportions of intermediate-skilled. The proportions of intermediate-skilled are remarkably large in Germany and Switzerland.

In the Netherlands the proportion of the population that is highly-skilled is relatively similar to that in many other countries, i.e. about $20 \%$ (see also Den Broeder, 1996). Only in the United States the proportion of highly-skilled is relatively large, whereas in Italy, Portugal and Spain the proportion of highly-skilled is relatively small.

If the results of table 2.8 are compared to the skill level of the total population in table 2.9 , we see that the share of intermediate-skilled technical workers in the total number of technical workers of the Netherlands is relatively large, namely $68 \%$ against $38 \%$ for the share of intermediate-skilled in the total population of the Netherlands. The share of highly-skilled technical workers in the total number of technical workers of the Netherlands is slightly below the share of highly-skilled in the total population of the Netherlands, namely $17.3 \%$ against $21 \%$ in table 2.9 . As a result, the share of lowskilled technical workers (as an approximation for the least able workers, see chapter 1) in the total number of technical workers is much lower than the share of low-skilled individuals in the total population, namely $14.7 \%$ against $40 \%$. It can be concluded that the low-skilled workers are underrepresented in technical occupations in the Netherlands, whereas the intermediate workers are overrepresented, which is favourable for economic growth. In most other countries selected the share of low-skilled in the total population approximately corresponds with the share of low-skilled in the total number of technical workers. Only Denmark shows a similar situation as the Netherlands.

Tables 2.10 and 2.11 focus on the educational level of the workers in the higher occupational classes of professionals and technicians, and the intermediate occupational classes of craft workers, operators and assemblers, respectively. Table 2.12 shows both the scientists and engineers and the technicians employed in R\&D jobs.

8. Note that the age groups of table 2.8 and 2.9 are not completely similar, since table 2.8 considers the level of education of all workers aged 15 years or more, whereas table 2.9 considers the level of education of the 25-64 age group. 
Table 2.9

Percentage of the population 25 to 64 years of age by the highest completed level of education, 1994

\begin{tabular}{rrrr}
\hline Country & $\begin{array}{r}\text { Low } \\
\%\end{array}$ & $\begin{array}{r}\text { Intermediate } \\
\%\end{array}$ & $\begin{array}{r}\text { High } \\
\%\end{array}$ \\
\hline
\end{tabular}

Key countries

\begin{tabular}{llrr} 
Denmark & 40 & 40 & 20 \\
Germany & 16 & 62 & 23 \\
Japan* & 27 & 49 & 24 \\
Netherlands & 40 & 38 & 21 \\
Switzerland & 18 & 61 & 21 \\
United Kingdom & 26 & 54 & 21 \\
United States & 15 & 53 & 32 \\
Other EU countries & & & \\
Belgium & & & \\
France & 51 & 27 & 17 \\
Greece & 33 & 50 & 18 \\
Ireland & 55 & 27 & 19 \\
Italy & 55 & 27 & 8 \\
Portugal & 67 & 26 & 10 \\
Spain & 81 & 8 & 15 \\
\hline
\end{tabular}

* data refer to 1990

Source: OECD, UNESCO

Table 2.10 gives a more specific view of the skill level of the workers employed in particular occupational fields. The table shows the average skill level in terms of years of education of technical workers in three different occupational classes of professionals and technicians for the 35-54 age group. ${ }^{9}$ The table indicates that for all three occupational classes the skill level index in the Netherlands is very low relative to both the key countries and the EU countries for all three occupational classes. The skill level index for computing professionals is high in Germany, Italy and Spain, whereas it is low in Denmark. The skill level index for architects and engineers is highest in Finland, Spain, Switzerland and Germany, whereas it is lowest in Sweden. The skill level index for science professionals is higher than 14 in the United Kingdom, whereas it is lower than 12 in France and Finland.

Table 2.11 shows the skill level index of the occupational classes of craft workers, operators and assemblers for the 35-54 age group. The table shows that the skill level index for the Netherlands is lower than 10 for all three occupational classes. Only Ireland, Italy and Spain have a skill level index lower than 10 for all three occupational classes. The skill level index is high in Germany, Switzerland, the United Kingdom and the United States for all three occupational classes.

9. The skill level index presented in tables 2.12 and 2.13 has some deficiencies due to the fact that only the theoretical number of years required to complete the level of educational attainment is used for calculation of the index, not the actual number of years. 
Table 2.10

Skill level index of professionals and technicians, 35-54 age group, 1992

\begin{tabular}{|c|c|c|c|}
\hline Country & $\begin{array}{c}\text { Computing } \\
\text { professionals* } \\
\text { years }\end{array}$ & $\begin{array}{c}\text { Architects } \\
\text { and engineers } \\
\text { years }\end{array}$ & $\begin{array}{c}\text { Science } \\
\text { professionals } \\
\text { years }\end{array}$ \\
\hline \multicolumn{4}{|l|}{ Key countries } \\
\hline $\begin{array}{l}\text { Denmark } \\
\text { Germany } \\
\text { Japan }\end{array}$ & $\begin{array}{l}12.8 \\
16.6\end{array}$ & $\begin{array}{l}15.4 \\
16.4\end{array}$ & $\begin{array}{l}12.2 \\
13.2\end{array}$ \\
\hline $\begin{array}{l}\text { Netherlands } \\
\text { Switzerland } \\
\text { United Kingdom } \\
\text { United States }\end{array}$ & $\begin{array}{l}14.2 \\
14.7 \\
15.5 \\
15.4\end{array}$ & $\begin{array}{l}14.2 \\
16.8 \\
15.6 \\
16.0\end{array}$ & $\begin{array}{l}12.0 \\
13.3 \\
14.1 \\
13.7\end{array}$ \\
\hline \multicolumn{4}{|c|}{ Other EU countries } \\
\hline $\begin{array}{l}\text { Austria } \\
\text { Belgium }\end{array}$ & . & & \\
\hline $\begin{array}{l}\text { Finland } \\
\text { France }\end{array}$ & $\begin{array}{l}14.3 \\
14.8\end{array}$ & $\begin{array}{l}17.4 \\
14.4\end{array}$ & $\begin{array}{l}13.0 \\
11.4\end{array}$ \\
\hline $\begin{array}{l}\text { Greece } \\
\text { Ireland }\end{array}$ & . & 13.7 & \\
\hline $\begin{array}{l}\text { Italy } \\
\text { Portugal }\end{array}$ & 16.0 & 16.0 & 12.3 \\
\hline $\begin{array}{l}\text { Spain } \\
\text { Sweden }\end{array}$ & $\begin{array}{l}17.0 \\
14.3\end{array}$ & $\begin{array}{l}17.0 \\
12.8\end{array}$ & $\begin{array}{l}12.1 \\
11.3\end{array}$ \\
\hline
\end{tabular}

${ }^{\star}=$ ISCO 213; ** = ISCO 214; ${ }^{* * *}=$ ISCO 31

Note: The skill level index is calculated by summing across ISCED levels the product of the fraction of workers in the occupational class who have completed education at a particular level and the typical number of years required to complete that level.

Source: OECD

Table 2.12 presents an indicator of the skill level of R\&D personnel. Scientists and engineers have usually completed scientific or technological training at the high-skill level, whereas technicians have received at least vocational or technical training at the intermediate-skill level (UNESCO, 1995). The indicator is calculated by relating the number of (highly-skilled) scientists and engineers to the number of (intermediate-

Table 2.11

Skill level index of craft workers, operators and assemblers, 35-54 age group (1992)

Extraction and
building workers $\quad \begin{gathered}\text { Precision and } \\ \text { printing workers }^{\star *}\end{gathered} \begin{gathered}\text { Operators and } \\ \text { assemblers }^{* * *}\end{gathered}$

Key countries

$\begin{array}{lrrr}\text { Denmark } & 11.7 & 11.4 & 9.5 \\ \text { Germany } & 11.7 & 11.6 & 10.2 \\ \text { Japan } & 9.9 & 9.5 & 9.0 \\ \text { Netherlands } & 11.7 & 12.3 & 10.7 \\ \text { Switzerland } & 12.1 & 11.8 & 11.2 \\ \text { United Kingdom } & 11.8 & 11.5 & 11.2\end{array}$


Table 2.11 (continued)

Skill level index of craft workers, operators and assemblers, 35-54 age group (1992)

\begin{tabular}{|c|c|c|}
\hline Countries & $\begin{array}{l}\text { Extraction and } \\
\text { building workers* }\end{array}$ & $\begin{array}{c}\text { Precision and } \\
\text { printing workers }\end{array}$ \\
\hline
\end{tabular}

Other EU countries

$\begin{array}{llrr}\text { Austria } & & . & \text {. } \\ \text { Belgium } & & 10 . & 10.0 \\ \text { Finland } & 10.4 & 10.4 & 7.5 \\ \text { France } & 8.9 & 10.2 & 8.0 \\ \text { Greece } & 8.4 & 9.0 & \text {. } \\ \text { Ireland } & 7.8 & 8.7 & 6.2 \\ \text { Italy } & 5.9 & 6.5 & 10.6 \\ \text { Portugal } & 5.9 & 11.0 & \text {. } \\ \text { Spain } & 10.9 & & \end{array}$

${ }^{*}=\operatorname{ISCO} 71{ }^{* *}=\operatorname{ISCO} 73 ;{ }^{* * *}=$ ISCO 80

Note: The skill level index is calculated by summing across ISCED levels the product of the fraction of workers in the occupational class who have completed education at a particular level and the typical number of years required to complete that level.

Source: OECD

skilled) technicians. The indicator shows that the skill level of R\&D personnel stands at an average level in the Netherlands, whereas it is high in Japan, Ireland and Spain.

Table 2.12

Indicator of the skill level of R\&D personnel, 1991

Country

Scientists and engineers per technician

ratio

Key countries

Denmark

West-Germany (1989)

Japan (1992)

Netherlands

Switzerland (1989)

United Kingdom

United States

Other EU countries

Austria (1989)

Belgium (1990)

Finland

France

Greece (1986)

reland (1988)

Italy (1990)

Portugal (1990)

Spain (1990)

Sweden

Source: UNESCO 


\subsection{Summary}

This chapter analysed the provision of technically skilled workers at the tertiary level of education and the employments share and skill level of technical workers in the Netherlands relative to other countries. As stated before, comparable data of the educational background of technically skilled workers of the Netherlands relative to other countries are only available for students, graduates and workers at the tertiary level of education. The share of the students of the various technical fields of study in the total number of students is small in the Netherlands $(18 \%)$, the United States $(16.6 \%)$ and Japan (19.7\%). Only the share of students at the tertiary level in trade, craft and industrial programs is relatively large in the Netherlands. The share of the total number of graduates at tertiary level in natural science, mathematics and computer science and engineering and architecture as well as the share of young workers with a tertiary science degree are also relatively small. However, with respect to the number of (highly-skilled) scientists and engineers and (intermediate-skilled) technicians per thousand population engaged in research and development, the Netherlands remarkably takes an intermediate position compared to the other industrialised countries.

In line with the above finding that the Netherlands has a relatively low provision of technically skilled workers, the employment share of technical workers in the Netherlands is the smallest of all countries in the sample (21\%). At all levels of education the Netherlands has the smallest employment share of technical workers of the key countries selected. In addition, the increase in the employment share of technical workers over time (the technical skill trend) in the Netherlands is only moderate. Both the low provision of technically educated workers and the low employment share of technical workers confirm the expectation stated in chapter 1 that the Netherlands has a low share of technical workers. To abstract from the sectoral production structure, the next chapter will look at the shares of technical workers within each sector, including the industrial sector.

Furthermore, among the technical workers the Netherlands has the largest share of intermediate-skilled workers $(68 \%)$ relative to all countries selected. The share of highlyskilled technical workers is at a rather average level, although much smaller than in the United States and Germany. Relative to the total population of the Netherlands the shares of intermediate-skilled and highly-skilled workers are over- and slightly underrepresented, respectively, in the total number of technical workers. It can be concluded that it is favourable for economic growth in the Netherlands that relatively few low-skilled individuals (who are assumed to represent the individuals with the lowest ability level, see chapter 1) of the total population in the Netherlands are employed in technical occupations. 
On the other hand, the skill level index measured by the average number of years of education for workers within particular technical occupations, namely professionals and technicians and craft workers, operators and assemblers, is low for the Netherlands relative to the other countries in the sample. Finally, the skill level of workers in R\&D jobs in the Netherlands is at an average level relative to the other countries. 


\section{Comparative sector analysis between countries}

\subsection{Introduction}

Comparing employment shares of technical workers between countries, as in section 2.3, does not account for differences of the sectoral production structure between countries. Countries with a large industrial sector can be expected to have large shares of technical workers. Therefore section 3.2 compares the employment shares of technical workers for the same economic sectors of the countries selected. Section 3.3 compares the skill level of these technical workers for each economic sector. An overview of the economic sectors that belong to the agricultural, industrial or services sector is given in appendix C. Section 3.4 summarizes.

\subsection{Employment shares of technical workers by economic sector (occupational background)}

Table 3.1 gives an overview of the employment shares of technical workers by economic sector. The table shows that the employment shares in agricultural, hunting, forestry and fishing are small relative to the average employment shares of technical workers at the country level (see table 2.8). In the Netherlands the sectoral employment share of technical workers in the agricultural sector is below the cross-country average of the agricultural sectors. ${ }^{10}$ The employment share of technical workers in this sector is the smallest in Greece and by far the greatest in Switzerland across the countries of the sample. ${ }^{11}$

The employment shares of technical workers in mining and quarrying are about twice as large as the country employment shares of technical workers (table 2.8) in most of the countries selected. The employment share of technical workers in mining and quarrying of the Netherlands is slightly larger than in mining and quarrying of most other countries. Germany, Italy and Portugal have the largest employment shares of technical workers, whereas Denmark and Japan have the smallest employment shares of technical workers in this economic sector across the countries of the sample.

The employment share of technical workers in manufacturing is even larger than in mining and quarrying for most countries. In particular in the economic sector of manufacturing technical workers may be of great importance for technological

10. It should be noted that the more or less technical agricultural occupations are not included here, since these occupations are not related to the fields of study in the ISCED classification that belong to the natural or technical sciences (see chapter 1).

11. Switzerland is the only country of the sample for which technical workers are defined by their educational background ('erlernter Beruf') instead of the occupational background. This may lead to statistical artefacts, in particular at sector level (see also some services sectors below). 
innovation and diffusion. It is most remarkably that the Netherlands, together with Switzerland, have the smallest employment shares of technical workers in manufacturing across the countries. In other words, the Netherlands, independent of the sectoral production structure, has a small employment share of technical workers in the manufacturing economic sector relative to the other countries. Italy, Portugal and France have the largest employment shares of technical workers in manufacturing across the countries.

Also in electricity, gas and water supply the employment shares of technical workers are large relative to the country averages of all sectors. The employment share of technical workers in the Netherlands is small in electricity, gas and water supply sector relative to the same sector in the other countries, although in the United Kingdom, the United States, Greece and Ireland these shares are even slightly smaller. Remarkably, Denmark has by far the largest employment share of technical workers in this sector across the countries.

For most countries it holds that the employment share of technical workers in construction is the largest across all economic sectors within a country. The employment share of technical workers in construction for the Netherlands is about average relative to the construction sector in the other sectors, whereas it is by far the smallest in Switzerland. In France and Greece the employment shares of technical workers in the construction sector across the countries are the largest.

The remaining economic sectors of table 3.1 are services sectors. These sectors are expected to have small employment shares of technical workers relative to the country averages, although there may be large differences between the various services sectors. This applies indeed to the employment share of technical workers in wholesale, retail trade and repairs. For this economic sector the employment share of technical workers in the Netherlands is slightly below the cross-country average of wholesale, retail trade and repairs, whereas it is relatively large in the United States and Italy.

The employment shares of technical workers in hotels and restaurants are very small relative to the other sectors within a country. The employment share of technical workers in hotels and restaurants across countries is by far the largest in Switzerland.

In transport, storage and communication the employment shares of technical workers are considerable for a services sector. Relative to the same sector in the other countries, the employment share of technical workers in transport, storage and communication is smallest in Ireland, Spain and the Netherlands, whereas it is by far the largest in Switzerland.

In financial intermediation the employment share of technical workers is small relative to the other sectors. It is by far the largest across countries in Switzerland, followed by 
Table 3.1

Employment shares of technical workers in the working population by economic sector, 1994

Country

Employment share

Agriculture, hunting, forestry and fishing

Key countries

Denmark

Germany

Japan

Netherlands

Switzerland*

United Kingdom

United States**

Other EU countries

Belgium

France

Greece

Ireland

Italy

Portugal

Spain

Mining and quarrying

Key countries

Denmark

Germany

Japan

Netherlands

Switzerland

41.3

United Kingdom

55.9

United States**

Other EU countries

Belgium

France

44.9

Greece

44.9
56.6

Ireland

43.8

Italy

-

Portugal

Spain

Manufacturing

Key countries

Denmark

Germany

Japan

Switzerland

42.7

United Kingdom

56.0

United States** 
Table 3.1 (continued)

Employment shares of technical workers in the working population by economic sector, 1994

Country

Employment share

Other EU countries

$\begin{array}{lc}\text { Belgium } & 62.9 \\ \text { France } & 68.4 \\ \text { Greece } & 64.3 \\ \text { Ireland } & 61.9 \\ \text { Italy } & 70.4 \\ \text { Portugal } & 68.5 \\ \text { Spain } & 66.8\end{array}$

Electricity, gas and water supply

Key countries

Denmark

Germany

54.5

Japan

50.3

Netherlands

62.7

United Kingdom

48.8

United States ${ }^{\star *}$

Other EU countries

Belgium

France

59.3

Greece

Ireland

Italy

Portugal

40.4

62.3

Spain

\section{Construction}

\section{Key countries}

Denmark

Germany

67.9

Japan

Netherlands

68.5

Switzerland*

United Kingdom

48.1

United States ${ }^{\star *}$

66.9
61.4

Other EU countries

$\begin{array}{lr}\text { Belgium } & 73.9 \\ \text { France } & 78.1 \\ \text { Greece } & 81.1 \\ \text { Ireland } & 61.8 \\ \text { Italy } & 73.2 \\ \text { Portugal } & 66.3 \\ \text { Spain } & 67.9\end{array}$


Table 3.1 (continued)

Employment shares of technical workers in the working population by economic sector, 1994

Country

Employment share

Wholesale, retail trade and repairs

Key countries

Denmark

Germany

15.6

Japan

Netherlands

14.8

Switzerland ${ }^{*}$

11.8

United Kingdom

14.0

United States**

Other EU countries

Belgium

France

Greece

Ireland

11.4

Italy

Portugal

Hotels and restaurants

Key countries

Denmark

Germany

Japan

Netherlands

United Kingdom

United States ${ }^{\star * *}$

Other EU countries

Belgium

France

Greece

Ireland

Italy

Portugal

Spain

Transport, storage and communication

Key EU countries

Denmark

Japan

Switzerland

United Kingdom

United States ** 
Table 3.1 (continued)

Employment shares of technical workers in the working population by economic sector, 1994

Country

Other EU countries

$\begin{array}{lr}\text { Belgium } & 18.2 \\ \text { France } & 14.4 \\ \text { Greece } & 18.8 \\ \text { Ireland } & 8.6 \\ \text { Italy } & 14.4 \\ \text { Portugal } & 20.5 \\ \text { Spain } & 12.9\end{array}$

\section{Financial intermediation}

Key countries

Denmark

Germany

Japan

Netherlands

Switzerland*

United Kingdom

United States**

Other EU countries

Belgium

France

Greece

Ireland

Italy

Portugal

Spain

Real estate, renting and business activities

Key countries

Denmark

Germany

Japan

Netherlands

Switzerland*

United Kingdom

United States**

Other EU countries

Belgium

France

Greece

Ireland

Italy

Portugal 
Table 3.1 (continued)

Employment shares of technical workers in the working population by economic sector, 1994

Country

Employment share

\section{Public administration}

Key countries

Denmark

Germany

Japan

Netherlands

11.7

Switzerland*

United Kingdom

United States ${ }^{\star \star}$

Other EU countries

Belgium

France

Greece

Ireland

Italy

Portugal

Spain

Other services

Key countries

$\begin{array}{lr}\text { Denmark } & 3.5 \\ \text { Germany } & 5.4 \\ \text { Japan } & 5.2 \\ \text { Netherlands } & 10.7 \\ \text { Switzerland } & 4.4 \\ \text { United Kingdom } & 4.9\end{array}$

Other EU countries

$\begin{array}{lr}\text { Belgium } & 5.3 \\ \text { France } & 7.4 \\ \text { Greece } & 4.5 \\ \text { Ireland } & 4.5 \\ \text { Italy } & 2.2 \\ \text { Portugal } & 2.9 \\ \text { Spain } & 3.7\end{array}$

* data for Switzerland refer to 1990 and are based on the educational background instead of the occupational background

** data refer to 1995

*** the technical workers of the United States in hotels and restaurants are included in other services

Source: Eurostat, Bundesamt für Statistik Switzerland, U.S. Census Bureau

the United States and the Netherlands. Italy and Spain have the smallest employment shares of technical workers in financial intermediation across the countries. 
Real estate, renting and business activities is the only services sector with employment shares of technical workers larger than $20 \%$ for most countries. In this sector the Netherlands has an average employment share of technical workers relative to the same sector in the other countries. Relative to the other countries the employment share of technical workers in real estate, renting and business activities is by far the largest in Germany and Switzerland, whereas it is the smallest in Ireland.

In public administration the employment share of technical workers is by far the largest in Switzerland across the countries of the sample. In the Netherlands the employment share is slightly above average relative to the public administration sector in the other countries.

For the other services sector it holds that the employment share in the countries selected is small relative to the other sectors. It is by far the largest in Switzerland, followed by France, relative to the other services sectors in the other countries.

\subsection{Educational attainment of technical workers by economic sector (occupational background)}

This section focuses on the skill level of the technical workers in the various economic sectors of the last section. This indication of the skill level of the technical workers is important because in particular technical workers at the intermediate-skill and high-skill level may be involved in technological innovation and the diffusion of technological developments. Table 3.2 shows the level of educational attainment of technical workers in the various economic sectors. Three skill levels of technical workers are distinguished: low, intermediate and high (see chapter 1). The table presents the shares of low-skilled, intermediate-skilled and highly-skilled technical workers in the total number of technical workers. We have excluded the economic sectors that revealed only small employment shares of technical workers in the last section.

In mining and quarrying Germany has not only the largest share of technical workers (see table 3.1), but also by far the largest share of intermediate-skilled technical workers in the total of technical workers employed. The Netherlands, the United Kingdom and France have also large shares of intermediate-skilled technical workers. The share of highly-skilled technical workers is remarkably large in Denmark, whereas it is very small in Portugal and Italy.

While the employment share of technical workers in manufacturing is small in the Netherlands relative to the other countries (see table 3.1), the share of intermediateskilled workers in the total of technical workers employed is the largest in the Netherlands: $69.9 \%$. Germany and Denmark also have large shares of intermediateskilled technical workers. The share of highly-skilled technical workers is relatively large 
in Germany and to a lesser extent in Ireland, whereas it is small in Italy, Portugal and Greece.

In electricity, gas and water supply the share of intermediate-skilled technical workers is largest in the Netherlands again, whereas the total employment share of technical workers is small in this economic sector in the Netherlands relative to other countries (table 3.1). Germany and France also have large shares of intermediate-skilled technical workers in electricity, gas and water supply. The share of highly-skilled technical workers is large in Denmark and to a lesser extent in the United States and in Spain. Italy and Portugal have the smallest shares of highly-skilled technical workers, followed by the Netherlands.

Construction also reveals the largest share of intermediate-skilled technical workers for the Netherlands. The shares of intermediate-skilled technical workers are large in Denmark, Germany and the United Kingdom, whereas the shares are small in Portugal and Spain. The shares of highly-skilled technical workers are relatively large in Germany and Ireland, whereas Portugal, the Netherlands, Greece and Italy have very small shares of highly-skilled technical workers.

The services sector wholesale, retail trade and repair also shows a relatively large share of intermediate-skilled technical workers for the Netherlands, followed by Denmark. Portugal and Spain have small shares of intermediate-skilled technical workers. The share of highly-skilled technical workers is remarkably large for Germany, whereas it is very small for Italy and Portugal.

Transport, storage and communication reveals a large share of intermediate-skilled technical workers in Germany, the Netherlands and France, whereas the share is relatively small in Portugal and Spain. The share of highly-skilled technical workers is large in Denmark and Spain, whereas it is very small in Italy.

Table 3.2

Skill level of technical workers by economic sector, 1994

\begin{tabular}{lrrr}
\hline Country & Low & Intermediate & High \\
$\%$ & $\%$
\end{tabular}

Mining and quarrying

Key countries

$\begin{array}{lrrr}\text { Denmark } & 0.0 & 37.1 & 62.9 \\ \text { Germany } & 13.7 & 69.3 & 17.1 \\ \text { Japan } & 5.3 & 59.0 & 35.7 \\ \text { Netherlands } & 33 . \dot{1} & 42.9 & 24.0 \\ \text { Switzerland } & \cdot & . & .\end{array}$


Table 3.2 (continued)

Skill level of technical workers by economic sector, 1994

\begin{tabular}{lrrr}
\hline Country & Low \\
$\%$ & $\begin{array}{r}\text { Intermediate } \\
\%\end{array}$ & $\begin{array}{r}\text { High } \\
\%\end{array}$ \\
\hline
\end{tabular}

Other EU countries

$\begin{array}{lrrr}\text { Belgium } & 49.3 & 29.8 & 21.0 \\ \text { France } & 34.2 & 47.1 & 18.7 \\ \text { Greece } & 70.2 & 21.3 & 8.5 \\ \text { Ireland } & 66.4 & 16.8 & 16.8 \\ \text { Italy } & 76.4 & 21.3 & 2.3 \\ \text { Portugal } & 95.9 & 4.1 & 0.0 \\ \text { Spain } & 73.1 & 9.3 & 17.6\end{array}$

Manufacturing

Key countries

Denmark

Germany

Japan

Netherlands

Switzerland

United Kingdom

United States

Other EU countries

Belgium

France

Greece

Ireland

Italy

Portugal

Spain

Electricity, gas, water supply

Key countries

Denmark
Germany
Japan
Netherlands
Switzerland
United Kingdom
United States
Other EU countries
Belgium
France
Greece
Ireland
Italy
Portugal
Spain

Spain
27.9

17.1

19.9

46.3

49.0

39.9

66.8

53.6

73.4

92.3

76.5
61.2
63.0

10.9

19.9

69.9

10.3

40.5

13.1

13.2

10.6

5.1

15.4
1.4

1.8

12.4

12.8

6.6

42.5

63.1

44.7

30.4

6.1

74.6

$19 . \dot{3}$

18.1

45.0

$36 . \dot{9}$

28.3

13.6

28.9

44.6

53.0

74.2

50.6

46.4

65.6

25.2

20.9

48.9

30.3

43.9

20.2

12.5

25.0

5.6

36.9 
Table 3.2 (continued)

Skill level of technical workers by economic sector, 1994

\begin{tabular}{lrrr}
\hline Country & Low & Intermediate & High \\
$\%$ & $\%$
\end{tabular}

\section{Construction}

Key countries

$\begin{array}{lc}\text { Denmark } & 13 \\ \text { Germany } & 13 \\ \text { Japan } & \\ \text { Netherlands } & 15 \\ \text { Switzerland } & \\ \text { United Kingdom } & 27 \\ \text { United States } & \\ \text { Other EU countries } & \\ \text { Belgium } & \\ \text { France } & 54 \\ \text { Greece } & 43 . \\ \text { Ireland } & 78 . \\ \text { Italy } & 54 \\ \text { Portugal } & 74 \\ \text { Spain } & 95 . \\ \end{array}$

$\begin{array}{lll}13.2 & 76.2 & 10.6\end{array}$

$\begin{array}{lll}76.8 & 69.8 & 17.1\end{array}$

Spain

Wholesale and retail trade; repair etc.

Key countries

Denmark
Germany
Japan
Netherlands
Switzerland
United Kingdom
United States

Other EU countries

Belgium
France
Greece
Ireland
Italy
Portugal
Spain

Transport, storage and communication

Key countries

Denmark
Germany
Japan
Netherlands
Switzerland
United Kingdom
United States

$15 . \dot{9} \quad 81 . \dot{5} \quad 2 . \overline{7}$

$\begin{array}{lll}27 . \dot{5} & 61 . \dot{8} & 10.7\end{array}$
74.4

54.6

$78 . \dot{9}$

33.9

8.0

8.1

56.7 
Table 3.2 (continued)

Skill level of technical workers by economic sector, 1994

\begin{tabular}{lrrr}
\hline Country & Low & Intermediate & High \\
$\%$ &
\end{tabular}

Other EU countries

$\begin{array}{lllr}\text { Belgium } & 38.9 & 43.7 & 17.4 \\ \text { France } & 22.2 & 63.1 & 14.7 \\ \text { Greece } & 19.6 & 46.6 & 33.8 \\ \text { Ireland } & 40.1 & 27.5 & 32.4 \\ \text { Italy } & 45.1 & 51.4 & 3.5 \\ \text { Portugal } & 64.9 & 17.8 & 17.3 \\ \text { Spain } & 38.5 & 21.8 & 39.7\end{array}$

Real estate, renting and business activities

Key countries

$\begin{array}{lrrr}\text { Denmark } & 6.3 & 40.4 & 53.3 \\ \text { Germany } & 1.5 & 27.3 & 71.2 \\ \text { Japan } & 5.5 & 45.1 & 49.3 \\ \text { Netherlands } & 17.3 & 27.2 & 55.5 \\ \text { Switzerland } & \cdot & \cdot & . \\ \text { United Kingdom } & & & \\ \text { United States } & & & \\ \text { Other EU countries } & 9.9 & 20.0 & 70.1 \\ \text { Belgium } & 16.8 & 37.5 & 76.6 \\ \text { France } & 5.5 & 17.5 & 72.2 \\ \text { Greece } & 8.6 & 19.2 & 32.4 \\ \text { Ireland } & 9.3 & 58.3 & 39.2 \\ \text { Italy } & 26.7 & 34.1 & 58.6 \\ \text { Portugal } & 20.1 & 21.2 & \\ \text { Spain } & & & \\ & & & \\ \text { Source: Eurostat } & & & \end{array}$

Source: Eurostat

The services sector with the largest employment share of technical workers, real estate, renting and business activities, shows the largest share of intermediate-skilled technical workers in Italy. The Netherlands also has a relatively large share of intermediate-skilled technical workers. The shares of highly-skilled technical workers in real estate, renting and business activities are generally very large across the countries selected. The shares of highly-skilled technical workers are even above $70 \%$ in Germany, Belgium, Greece and Ireland.

\subsection{Summary}

The empirical findings of this chapter provide an answer to the question raised in chapter 1 whether the expected relatively small employment share of technical workers in the Netherlands is due to the services-oriented sector structure of the Dutch economy or not. The data show that the services sectors indeed exhibit smaller employment 
shares of technical workers than the industrial sectors of all countries in the sample. However, the findings also indicate that the Netherlands has relatively small employment shares of technical workers in three economic sectors, i.e. electricity, gas and water supply, manufacturing and transport, storage and communication, whereas the employment shares of technical workers in the Netherlands are slightly above the cross-country average in mining and quarrying and financial intermediation.

With regard to the educational attainment of technical workers, it can be concluded that the share of intermediate-skilled technical workers in the total number of technical workers is large in the Netherlands for most economic sectors relative to the economic sectors of the other countries. This holds in particular for the industrial sectors. In most economic sectors the share of highly-skilled technical workers in the total number of technical workers of the Netherlands relative to the other industrialised countries is about average. Both findings reflect the respective shares of intermediate and highlyskilled workers at the aggregate level in the Netherlands relative to other industrialised countries, as indicated in chapter 2 . 


\section{Conclusions and summary}

\subsection{General conclusions}

Both adequate employment of technical workers and an adequate skill level of these workers constitute the basis for continuous technological development and economic growth. Therefore the provision, employment and educational attainment of technically skilled workers can be an important policy instrument for the Dutch government to stimulate economic growth. However, due to the relatively small industrial sector and the relatively large services sector the Netherlands is expected to have a proportionally small provision and employment share of technically skilled workers relative to other industrialised countries.

The report focuses on four questions:

1. Is the expectation justified that both the provision and the employment of technically skilled workers in the Netherlands are low relative to other industrialised countries? This was the main question of the report. The available data indeed confirm the low provision of technically (highly)-skilled workers as well as the low employment share of technical workers in the Netherlands relative to other industrialised countries. The Netherlands has, after the United States, the smallest share of students enrolled in the various technical fields of study in higher education (18\%). In addition, the Netherlands has the lowest employment share of technical workers $(21 \%)$ of all countries selected.

2. Is the assumption justified that the employment share of technical workers in the services sector is low relative to the industrial sector?

The available data indeed reveal that in all countries the services sectors have smaller employment shares of technical workers than the industrial sectors. This finding justifies the assumption on which the expectation mentioned in the first question is based.

3. How large are the employment shares of technical workers at sector level across countries?

This question was asked to exclude the impact of the sectoral distribution on the share of technical workers. It can be concluded that the relatively low share of technical workers is not merely related to the sector structure of employment. In many economic sectors of the Netherlands the employment shares of technical workers are below average. The employment share of technical workers in the manufacturing sector of the Netherlands is, after Switzerland, the smallest (50\%) of all countries selected.

From the above three findings, the important conclusion can be drawn that the relatively small employment share of the Netherlands at the country level is the result of both the services-oriented sector structure of the economy and the relatively small employment shares of technical workers in many economic sectors, including manufacturing. 


\section{What is the level of education of technical workers in the Netherlands relative to other}

industrialised countries?

It was found that the employment share of intermediate-skilled workers in technical occupations in the Netherlands is the largest $(68 \%)$ relative to the other industrialised countries. It was shown that the ablest share of the population (i.e. the sum of the intermediate and the highly-skilled) in the Netherlands is overrepresented in the most productive occupations, including the technical occupations. The fact that workers with the highest ability level in the Netherlands are relatively often employed in technical occupations is favourable for economic growth. However, in some technical occupations in the Netherlands, the skill level index measured by the average number of years of education is low relative to other industrialised countries.

An important point of interest is whether the relatively low provision of technically (highly)-skilled workers in the Netherlands is determined by the economic structure of the Netherlands or the relatively low provision of technically skilled workers is a major disadvantage for firms that need these workers (e.g. firms in the industrial sector) to start or expand their business in the Netherlands. The Netherlands is known for its relatively large services sector, which partly explains the small employment share of technical workers at the national level. However, this cannot explain the small employment share of technical workers in the manufacturing sector of the Netherlands. If the demand for technical workers by the manufacturing sectors is assumed to be similar across industrialised countries then the relatively low employment share of technical workers in the Netherlands is probably to a large extent due to the relatively low supply of technically educated workers on the Dutch labour market. However, further research is required to investigate the interdependencies between demand and supply of technical workers in the Netherlands.

\subsection{Summary of data analysis}

\section{Provision of technically skilled workers}

Comparable data of the educational background of technically skilled workers in the Netherlands relative to other countries are only available for students, graduates and workers at the tertiary level of education. The share of the students of the various technical fields of study in the total number of students is small in the Netherlands $(18 \%)$, the United States (16.6\%) and Japan (19.7\%). Only the share of students at the higher level in trade, craft and industrial programs is relatively large in the Netherlands. The shares of the total number of graduates at tertiary level in natural science, mathematics and computer science and engineering and architecture as well as the share of young workers with a tertiary science degree are also relatively small. However, with respect to the number of (highly-skilled) scientists and engineers and (intermediate-skilled) technicians engaged in research and development per thousand persons, the Netherlands remarkably takes an intermediate position compared to the other industrialised countries. 


\section{Employment shares of technical workers}

The employment share of technical workers in the Netherlands is the smallest of all countries in the sample (21\%). At all levels of education, the Netherlands has the smallest employment share of technical workers of the key countries selected. In addition, the increase in the employment share of technical workers over time (the technical skill trend) in the Netherlands is only moderate. Moreover, the data show that the services sectors exhibit smaller employment shares of technical workers than the industrial sectors of all countries in the sample. The findings also indicate that the Netherlands has relatively small employment shares of technical workers in three economic sectors, i.e. electricity, gas and water supply, manufacturing and transport, storage and communication, whereas the employment shares of technical workers in the Netherlands are slightly above the cross-country average in mining and quarrying and financial intermediation.

\section{Educational attainment of technical workers}

Among the technical workers, the Netherlands has the largest share of intermediateskilled workers $(68 \%)$ relative to all countries selected. The share of highly-skilled technical workers is at a rather average level, although much smaller than in the United States and Germany. Relative to the total population of the Netherlands, the shares of intermediate-skilled and highly-skilled workers are over- and slightly underrepresented in the total number of technical workers, respectively. On the other hand, the skill level index measured by the average number of years of education for workers within particular technical occupations, namely professionals and technicians and craft workers, operators and assemblers, is low for the Netherlands relative to the other countries. Lastly, the skill level of workers in R\&D jobs in the Netherlands is at an average level relative to the other countries. 


\section{References}

Borghans, L., A. de Grip and W. Smits (1995), Beroepsmobiliteit van Technisch Opgeleiden, OSAD1, The Hague.

Broeder, C. den (1996), Institutions at work: Commitment and flexibility on the German and Dutch labour markets, Research Memorandum No. 131, CPB Netherlands Bureau for Economic Policy Analysis, The Hague.

Bundesamt für Statistik (1990), Population Census 1990, Bern, Switzerland.

CBS (1996), Kennis en economie 1996, Voorburg/ Heerlen.

Cörvers, F. (1997), The Impact of Human Capital on Labour Productivity in Manufacturing Sectors of the European Union, forthcoming in Applied Economics.

Cörvers, F. and A. de Grip (1997), Explaining Trade in Industrialized Countries by Country-Specific Human Capital Endowments, forthcoming in Economic Modelling.

Cörvers, F. and F.K. Reininga (1996), Analyzing Relative Factor Inputs of Dutch Exports: an application of the 1991 social accounting matrix for the Netherlands, National Accounts, Statistics Netherlands, Occasional Paper No. NA-069, Voorburg.

Duijn, J.J. van (1992), Investeren in mensen en welvaart; in C.P.A. Bartels (ed.), Investeren in mensen en economisch rendement, Van Gorcum, Assen/ Maastricht, 1992.

Eurostat (1992), Labour Force Survey, Methods and definitions, Luxembourg.

Geelhoed, L.A. (1997), 1997: Een Delta in Europa, Economisch Statistische Berichten, Vol. 82, pp. 4-8.

Hoevenberg, J. and A. de Grip (1994), Monitoring Skill Potentials for Technological Innovation and Diffusion, ROA-R-1994/14E, Maastricht.

Murphy, K.M., A. Shleifer and R.W. Vishny (1991), The Allocation of Talent: Implications for Growth, Quarterly Journal of Economics, Vol. 106, pp. 503-530.

OECD (1995), OECD Education Statistics 1985-1992, Paris.

OECD (1996), Employment Outlook, Paris.

OECD (1996a), Education at a Glance, Paris.

Research Centre for Education and the Labour Market (1995), The Labour Market by Education and Occupation to 2000, ROA-R-1995/3E, Maastricht.

Soete, L. and B. Verspagen (1993), Onderwijs en onderzoek: voedingsbodem voor groei, Economisch Statistische Berichten, Vol. 78, pp. 876-879.

Statistics Bureau Japan (1990), Population Census of Japan, Vol. 5, Part 1, Management and Coordination Agency, Tokyo.

Statistics Bureau Japan (1994), Report on the Special Survey of the Labour Force Survey, Management and Coordination Agency, Tokyo.

UNESCO (1995), Statistical Yearbook 1995, Paris.

U.S. Census Bureau (1995), Current Population Survey, Washington. 


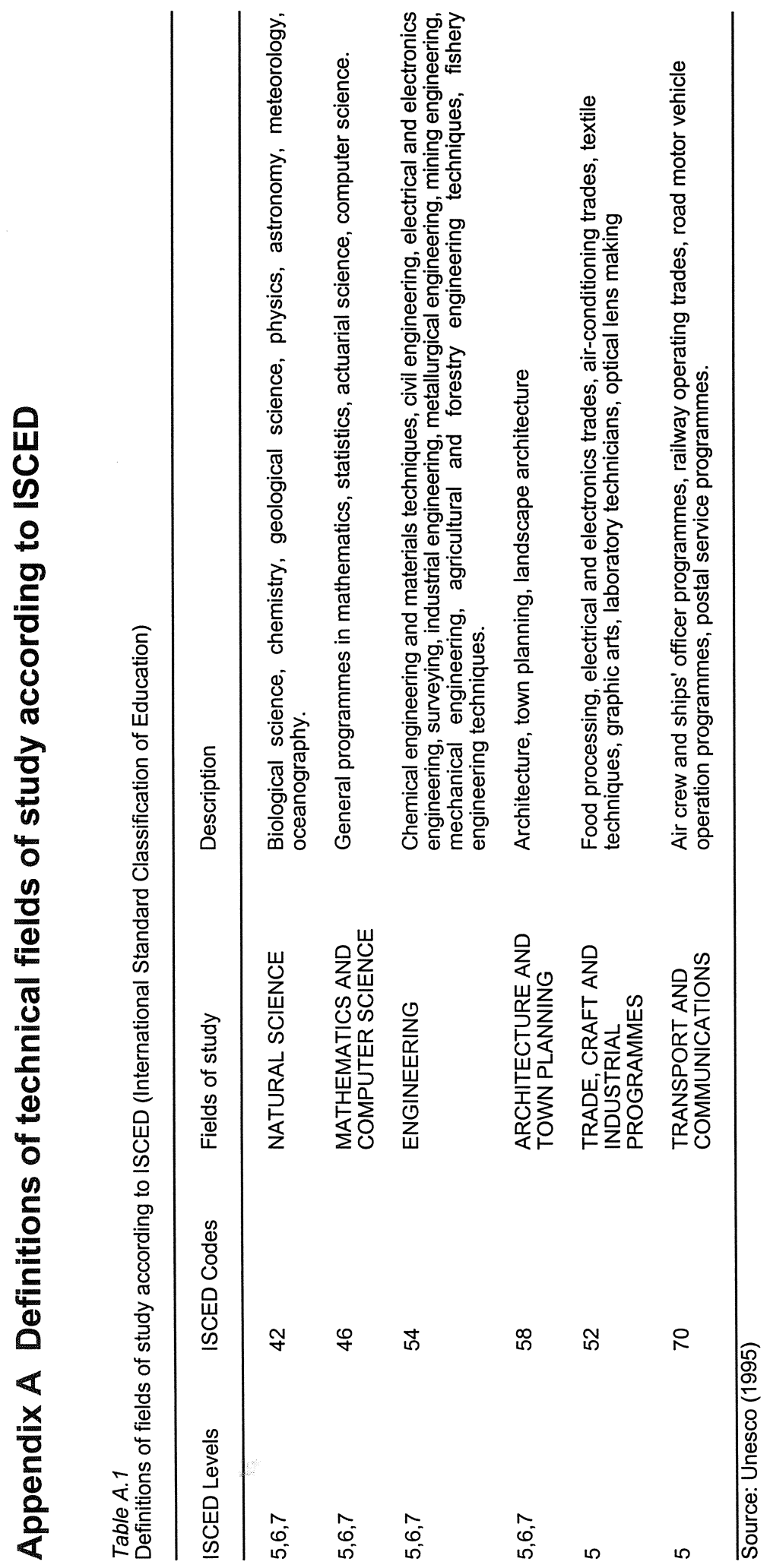




\section{Appendix B Definitions of technical occupations}

Table B. 1

Definitions of technical occupations according to ISCO 88

\begin{tabular}{|c|c|}
\hline ISCO 88 & Technical occupations \\
\hline $\begin{array}{l}2 \\
21 \\
211 \\
212 \\
213 \\
214\end{array}$ & $\begin{array}{l}\text { Professionals } \\
\text { Physical, mathematical and engineering science professionals } \\
\text { Physicists, chemists and related professionals } \\
\text { Mathematicians, statisticians and related professionals } \\
\text { Computing professionals } \\
\text { Architects, engineers and related professionals }\end{array}$ \\
\hline $\begin{array}{l}3 \\
31 \\
311 \\
312 \\
313 \\
314 \\
315\end{array}$ & $\begin{array}{l}\text { Technicians and associate professionals } \\
\text { Physical and engineering science associate professionals } \\
\text { Physical and engineering science technicians } \\
\text { Computer associate professionals } \\
\text { Optical and electronic equipment operators } \\
\text { Ship and aircraft controllers and technicians } \\
\text { Safety and quality inspectors }\end{array}$ \\
\hline $\begin{array}{l}7 \\
71 \\
711 \\
712 \\
713 \\
714\end{array}$ & $\begin{array}{l}\text { Craft and related trade workers } \\
\text { Extraction and building trades workers } \\
\text { Miners, shotfirers, stone cutters and carvers } \\
\text { Building frame and related trades workers } \\
\text { Building finishers and related trades workers } \\
\text { Painters, building structure cleaners and related trades workers }\end{array}$ \\
\hline $\begin{array}{l}72 \\
721\end{array}$ & $\begin{array}{l}\text { Metal, machinery and related trades workers } \\
\text { Metal moulders, welders, sheet-metal workers, structural-metal } \\
\text { preparers, and related trades workers }\end{array}$ \\
\hline $\begin{array}{l}722 \\
723 \\
724\end{array}$ & $\begin{array}{l}\text { Blacksmiths, tool-makers and related trades workers } \\
\text { Machinery mechanics and fitters } \\
\text { Electrical and electronic equipment mechanics and fitters }\end{array}$ \\
\hline $\begin{array}{l}73 \\
731 \\
732 \\
733 \\
734\end{array}$ & $\begin{array}{l}\text { Precision, handicraft, craft printing and related trades workers } \\
\text { Precision workers in metal and related materials } \\
\text { Potters, glass-makers and related trades workers } \\
\text { Handicraft workers in wood, textile, leather and related materials } \\
\text { Craft printing and related trades workers }\end{array}$ \\
\hline $\begin{array}{l}74 \\
741 \\
742 \\
743 \\
744\end{array}$ & $\begin{array}{l}\text { Other craft and related trades workers } \\
\text { Food processing and related trades workers } \\
\text { Wood treaters, cabinet-makers and related trades workers } \\
\text { Textile, garment and related trades workers } \\
\text { Pelt, leather and shoemaking trades workers }\end{array}$ \\
\hline $\begin{array}{l}8 \\
81 \\
811 \\
812 \\
813 \\
814 \\
815 \\
816 \\
817\end{array}$ & $\begin{array}{l}\text { Plant and machine operators and assemblers } \\
\text { Stationary-plant and related operators } \\
\text { Mining and mineral-processing-plant operators } \\
\text { Metal-processing plant operators } \\
\text { Glass, ceramics and related plant operators } \\
\text { Wood-processing- and papermaking-plant operators } \\
\text { Chemical-processing-plant operators } \\
\text { Power-production and related plant operators } \\
\text { Industrial robot operators }\end{array}$ \\
\hline
\end{tabular}


Table B.1 (continued)

Definitions of technical occupations according to ISCO 88

ISCO 88

Technical occupations

82

821

822

823

824

825

826

827

828

829
Machine operators and assemblers

Metal- and mineral-products machine operators

Chemical-products machine operators

Rubber- and plastic-products machine operators

Wood-products machine operators

Printing-, binding- and paper-products machine operators

Textile-, fur- and leather-products machine operators

Food and related products machine operators

Assemblers

Other machine operators not elsewhere classified

Source: Eurostat (1992) 


\section{Appendix C Definitions of economic activities}

Table C.1

Definitions of economic activities according to NACE rev. 1.

NACE Rev. 1 Economic Activities (called economic sectors in this report)

Code

Agriculture, hunting, forestry and fishing

Mining and quarrying

Manufacturing

Electricity, gas and water supply

Construction

Wholesale and retail trade, repairs

Hotels and restaurants

Transport, storage and communication

Financial intermediation

Real estate, renting and business activities

Public administration

Other services

Source: Eurostat (1992)

Table C. 2

Definitions of sectors according to NACE rev. 1.

NACE Rev. 1 Sectors

Code

Agriculture

Industry

Services

Source: Eurostat (1992)

The following symbols are used in the tables of this report: category not available or data not available

magnitude nil 
$\ldots$ 


\title{
Appendix D Contact persons
}

\author{
United Kingdom
}

Mr Rob Wilson

Institute of Employment Research

Mr John Cuthbert, Mrs Jayne Middlemas, and Mrs Civ Cromtton

Department for Education and Employment

Denmark

Mr Kaj Olesen

Danish Technological Institute

Mrs Metter Bier Paulsen

Vocational Education and Training

Danish Ministry of Education

\section{Germany}

Mr Hans Dietrich

Institut für Arbeitmarkt- und Berufsforschung

Switzerland

Mr Fritz Spahni and Mr. Dominik Ullmann

Bundesamt für Statistik

Mr Jaap van Dam

Forschungsinstitut für Arbeit und Arbeitsrecht

United States

Mrs Paula Knepper

United States Department of Education

National Center of Education Statistics

Mrs Rosalind Bruno

United States Census Bureau 
Japan

Mr P.W.Th. Ghijsen

Erasmus Centre for Labour Market Analysis

Faculty of Economics

Erasmus University Rotterdam

Mr Hiroshi Nishizawa

The Japan Institute of Labour

Mr Hiroyuki Tomizawa

Science and Technology Agency

National Institute of Science and Technology Policy

OECD

Mr Albert Tuynman

Education and Training Division

Paris

Statistical office of the European Communities

Didier Lesnicki

Directorate E

Luxembourg 